\title{
Water Vendor and Domestic Water Needs in Peri-Urban: A Case of Gwagwalada Town, Gwagwalada Area Council Federal Capital Territory (Fct), Nigeria
}

\section{Omotoso $\mathbf{0}^{1 *}$ and Akanbi $\mathrm{OA}^{2}$}

1Department of Geography \& Planning Science, Ekiti State University, Nigeria

${ }^{2}$ Department of Geography \& Environment Management, University of Abuja, Nigeria

*Corresponding author: Omotoso Oluwatuyi, Department of Geography \& Planning Science, Ekiti State University, Ado-Ekiti, Ekiti State, Nigeria, Tel: 08035749120;

Research article

Volume 2 Issue 6

Received Date: October 17, 2018

Published Date: November 16, 2018

DOI: $10.23880 /$ jenr-16000149

Email: oluwatuyi.omotoso@eksu.edu.ng

\section{Abstract}

Water is a major determinant of status of human existence and its socio-economic activities. This is partly due to its role in stemming growing trend in water-borne diseases with its attendant problems. However, the availability of potable water in the areas varies from those in the urban area. The urban areas enjoy more of potable water than the rural areas. In FCT, Nigeria the number of people outweigh the available potable water, thus people are forced to look for water for their needs through various methods, including water vendor. Water vendor is an unconventional method of sourcing water involving the use of truck, plastic container among others. The study involved 400 respondents in Gwagwalada Area Council, FCT- Nigeria. In all, interviews were conducted and questionnaires were also administered in the randomly selected settlements of the wards on the subject matter. Data from all these sources were subjected to simple descriptive statistic of simple chi-square analysis. The result shows that, table value is $\mathrm{X}^{2} 0.05,9=16.9$, while the calculated value is 0.25; there is no significant relationship between water vendor and water needs of people of Gwagwalada Area Council, FCT-Nigeria. The study reveals that water vendor is still relevant among the peri-urban populace in FCT, Abuja, Nigeria. This may be as a result of unavailability of potable water in the study area, because of neglect on the part of government. The study therefore recommends that, water vendor should be regulated to make it a reliable source of water.

Keywords: Water Vendor; Peri-Urban; Domestic water

\section{Introduction}

Water is key to the development of any human society as a stabilizer of the social system. Jabeen, et al. submitted that inadequate potable water is the second most important risk factor for poor health in many third world countries [1]. It is one of the most deadly threats for children (World Vision Australia, 2015) and indeed any human society; water is essential for the continuous existence of human and animals [2]. It is of the basic requirement for life. It ranks second to air in order of 
importance and about $70 \%$ of the surface of the earth is covered with water inform of oceans, lakes, rivers etc [3].

It also brings a multitude of economic and social benefits [4]. Furthermore, UNESCO (n.d) affirms that, water is a key factor in the creation of jobs, as water shortages and problems of access to water and sanitation could limit economic growth and job creation; it is also essential domestic and an element of psychological welfare [5]. Thus, Muta'a Hellandendu (Date not stated) submits that, availability of potable water can help in the improvement of social well-being of the population directly. Above all, it is vital for reducing the global burden of disease and improving the health, welfare and productivity of populations [6]. For instance, diarrhea (a waterborne disease) is estimated to cause 1.7 million deaths per year, mostly among children under five living in developing countries and second leading cause of death in children under five years old [7].

However, WHO/UNICEF submitted that, 2.1 billion people lack access to safely managed drinking water services globally [8]. The United Nations International Children's Fund opines further that, availability of potable water is expected to decrease in many regions in the next few years from now [9]. Furthermore, The United Nations affirms that $85 \%$ of the world population lives in the driest part of the planet [10]. As result of the above, people are forced to get their water from questionable sources. The situation is even precarious in Africa, where water availability is expected to decrease in many regions. The benefits of having access to an improved drinking water source can only be fully realized when there is also access to improved sanitation and adherence to good hygiene practices. In Nigeria, Over 57 million Nigerians still drink water from rivers, lakes, ponds, streams and irrigation canals [11].

According to Bello [12], Federal Capital Territory has dam reservoir of a 100 million metric tonnes of raw water supply at the Lower Usuma Dam with a backup supply of 850 million metric tonnes available from the Gurara Dam to care for an estimated population which National Population Commission [13] put at 3,564,100 people. This implies that, only few people meet the World Health Organization (WHO) water requirement of between 50 and 100 litres of water per person per day [14]. This explains major troubling paradoxes in life in Nigeria particularly the provision of potable water supply and country's population growth and by extension contributed to poverty level globally [15].
In addition, there are four treatment plants in operation which have a collective treatment capacity of 30,000 metric tonnes per hour. There are also several storage tanks all around the city of various capacities ranging from 3,000 to 45,000 metric tonnes which serve for effective distribution of water supply across the capital city and its environs.

World Bank [16] submitted that, in Nigeria fewer than $10 \%$ of its city dwellers have access to potable water in 2015, down from 29 per cent in 25 years earlier i.e. 1990. This has also resulted in deaths from water related diseases. Corcoran et al as cited by UNICEF [9] submitted that $90.0 \%$ of wastewater in developing countries flow into rivers, and lakes, without being collected or treated, and thus, threatening safe drinking water and bathing water. This is a similar scenario in Nigeria, where water supply is not sufficiently provided [17].

In order to arrest the dangers inherent in inadequate water scarcity, many countries such as Nigeria, South Africa, India, Bangladesh and Malawi, a lot of strategies have been put in place. [8] Submitted that, 159 million people still use surface water, and two third live in subSaharan Africa. In Nigeria, National Rural Water Supply and Sanitation Strategic Framework were conceived by the Federal Government of Nigeria to curtail these shortfalls in availability [18]. This document still remains a working document in Nigeria till date. Additionally, because of challenges in the execution of this programme, people have also adopted various ways of sourcing for water for their domestic and other uses.

\section{Statement of the Problem}

Water is life. Its importance in the socio-economic development of any nation cannot be over-emphasized. The small proportion of water available in form of fresh water has been constantly polluted due to various activities of man, thereby, leading to serious water related problems [19]. Ayoade [3], sees water as one of the ingredients for human consumption and sanitation. It is used for recreation, production of food and fibre. Water is used for irrigation, since crops and plants depend on water for their survival.

According to UNCHS [20], out of the total quantity of water available, about 3percent is fit for human consumption (fresh water). The water needed for domestic purposes should be free from toxic minerals. Despite the importance of water in development, the 
availability of safe water in Nigeria especially in Gwagwalda area of FCT is fast becoming one of the most important factors limiting socio-economic development a crucial visible indicator of the quality of the environment and a cause of national and international social conflicts.

In most Nigerian urban areas, people resort to alternative sources of water in the face of public water supply, such as vendors selling water of unverifiable provenance and quality.

Water vending refers to the formal or informal reselling or onward distribution of utility water, or water from other sources by small-scale vendors for domestic use such as water kiosks, water carriers, tanker trucks, households reselling water from their utility water connections among others. According to Olajuyigbe. et al, water vendor is a way of collecting water through unconventional ways.

Olajuyigbe, et al. identifies two types of water vendingformal and informal vendors. Formal vendors obtain their water from improved sources, while most informal vendors obtain their water from questionable sources. Water vending practices are provided through cart with small tank/drum, tanker truck among others [21].

Merriam Webster (n.d.) defines peri-urban as an area immediately surrounding a city or town. It is characterised by poor infrastructural development such as poor road network, limited access to water supply, poor electricity supply and inadequate access to improved sanitation facilities among others. The areas are usually densely populated thereby worsening the already dilapidated or non-existing infrastructural facilities [9].

These attributes are not without their challenges; however, this study is limited to vending as a method of accessing water in the peri-urban area of Gwagwalada town in the Gwagwalada Area Council of FCT-Nigeria.

Therefore, the aim of this study is to establish the relationship between water vendor practices and domestic water needs in peri-urban, using Gwagwalada town in Gwagwalada Area Council of Federal Capital Territory as a case study. This aim is achieved through the following objectives: examine the sources of water, evaluate the available alternatives to public water in the study area, evaluate water vendor system and examine the relationship between water vendor and health of the populace of Gwagwalada Area Council, FCTNigeria.

\section{Hypothesis}

Ho: There is no significant relationship between water vendor and domestic water needs in peri-urban of Gwagwalada Area Council, FCT-Nigeria.

\section{The Study Area}

Gwagwalada Area Council is one of the six area councils in Federal Capital of Nigeria; it is located between $8^{\circ} 56^{\prime} 29^{\prime \prime}$ North and $7^{\circ} 5^{\prime} 31^{\prime \prime}$ East.

It is bordered in the South by Kwali Area Council, in the North by Niger State; Kuje Area Council in the East and AMAC in the North-East. The study area occupies a land area of about $1,043 \mathrm{~km}^{2}$. The topography of the study area is ranged with numerous valleys view hills, with Zuba hills at the north west of the territory. It is also drained by river Usuma. It has tropical climate, with the temperature ranging from $30^{\circ}-37^{\circ} \mathrm{C}$, with the highest recorded in the month of March; the annual mean annual temperature of $1,650 \mathrm{~mm}$. It is estimated to have a population of 402,000, with population density of $385.4 / \mathrm{km}^{2}$ (National Population Commission of Nigeria [13].

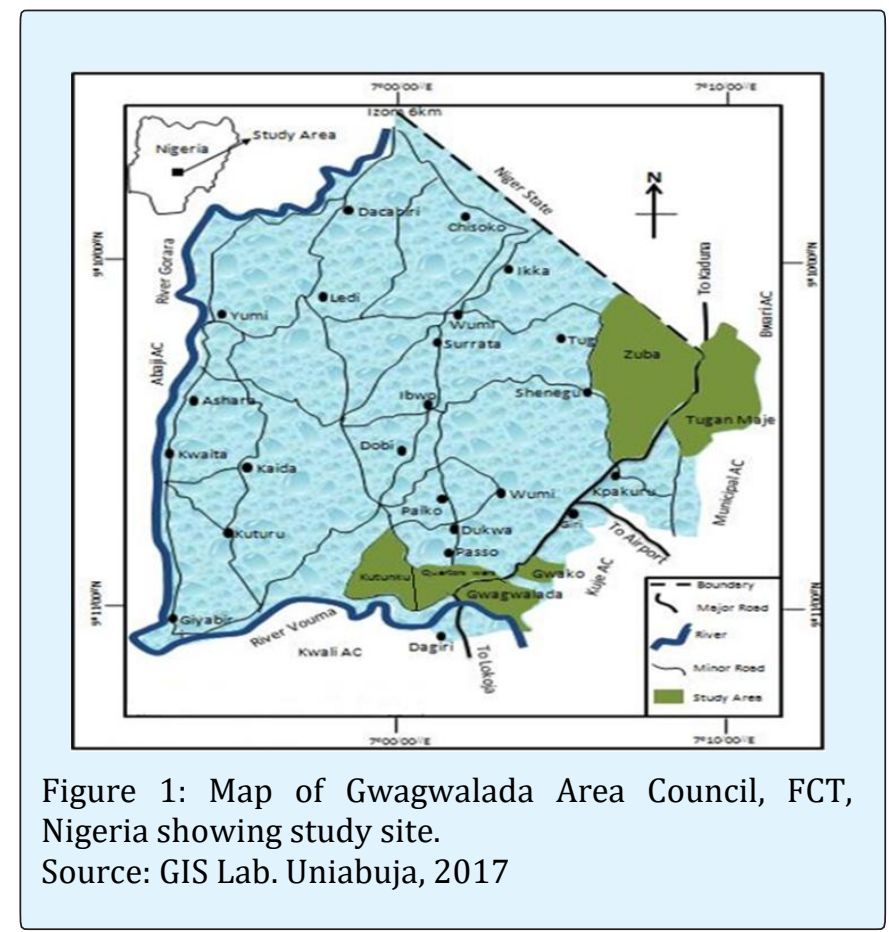




\section{Research Methods}

Socio-Economic Characteristics of the Respondents: This part of the study explains the socio-economic characteristics of the respondents in relation to sex, marital status, occupation, educational attainment, religion and income.

\begin{tabular}{|c|c|c|}
\hline Item & Frequency & Percentage \\
\hline \multirow{2}{*}{ Sex } & Male(100) & Male (25) \\
& Female(300) & Female(75) \\
\hline \multirow{2}{*}{ Marital Status } & Married(380) & Spinster (5) \\
\hline \multirow{3}{*}{ Occu } & Spinster(20) & Farming(5.0) \\
pation & Farming(20) & Business(13.7) \\
& Business(55) & Professional(15.0) \\
& Professional(60) & Artisan(25.0) \\
& Artisan(100) & Civil Service (35.0) \\
& Civil Service (140) & Fnemployed(6.3) \\
\hline \multirow{2}{*}{ Education } & Unemployed(25) & None (15) \\
\hline \multirow{5}{*}{ Income } & Formal(340) & Less N5,000 (50) \\
& None (60) & $\mathrm{N} 5,000-\mathrm{N} 10,000(20)$ \\
& Less $\mathrm{N} 5,000(200)$ & $\mathrm{N} 11,000-\mathrm{N} 16,000(10)$ \\
& $\mathrm{N} 5,000-\mathrm{N} 10,000(80)$ & $\mathrm{N} 17,000-\mathrm{N} 22,000(6.2)$ \\
& $\mathrm{N} 11,000-\mathrm{N} 16,000(40)$ & $\mathrm{N} 23,000-\mathrm{N} 28,000(11.3)$ \\
& $\mathrm{N} 17,000-\mathrm{N} 22,000(25)$ & More than N29,000(2.5) \\
\hline
\end{tabular}

Table 1: Distribution of Respondents by Socio-Economic Characteristics.

Source: Field Survey, 2017.

The profile of respondents in Table 1 shows that, $25.0 \%$ were male, while the remaining $75.0 \%$ were female. This may be aligned to the fact that, in Africa society, discussions that has to with family, lies with heads, who are mostly men. Furthermore, $95.0 \%$ of the respondents were married, while $5.0 \%$ are spinsters. The married were able to give detail knowledge of what they understand as traditional medicine, and whether it should be encouraged or not. In the same vein, majority of the respondents were civil servants as they constitute $35.0 \%$ of the respondents, while artisans came second constituting $25.0 \%$. The others in this study include the bricklayers, carpenters, plumbers among others. Furthermore, $13.7 \%$ and $15.0 \%$ of the respondents were in business and professional respectively. Lastly, $6.3 \%$ of respondents were unemployed. Similarly, Table 1 reveals that, $50 \%$ of respondents earn less than N5, 000 per month, while $20 \%$ earns between $\mathrm{N} 5,000$ and $\mathrm{N} 10,000$. In the same vein $10.0 \%$ of respondents earn between $\mathrm{N} 11$, 000 and $\mathrm{N} 16,000$ and $6.2 \%$ earns between $\# 17,000$ and
N22, 000 monthly. Suffice to add that $11.3 \%$ earns between N23, 000 and N28, 000.

From the above scenario, majority of the respondents earns less than N170.0 per day, which translates to US $\$ 1.13$ per day. This fall short of US $\$ 1.25$ or N187.5 recommended for an individual by the World Bank.

\section{Methodology}

The data used in this study were obtained from primary and secondary sources. The secondary source included National Population Commission (NPC) publications and maps, while the primary source involved were questionnaire and interview. In obtaining relevant data for the study, Purposive and Proportional Probability to Size (PPS) sampling techniques were adopted. The choice of purposive sampling method was informed because it reaches a targeted sample quickly and that was selected based on characteristics. 


\begin{tabular}{|c|c|}
\hline S/N & Ward \\
\hline I & Paiko-Kore \\
\hline Ii & Ibwa \\
\hline Iii & Dobi \\
\hline Iv & Ikwa \\
\hline V & Tunga-Maje \\
\hline Vi & Gwako \\
\hline Vii & Quarters(Phase i, ii \&ii) \\
\hline Viii & Kuntunku \\
\hline Ix & Zuba \\
\hline X & Central \\
\hline Total & 10 \\
\hline
\end{tabular}

Table 1: Wards in Gwagwalada Area Council. Source: Field Survey, 2017.

The study area has ten wards, out of which six wards were randomly selected; the purposively selected wards were chosen, because of their uniqueness in terms of population and water needs. The sample size of 400 using Proportional Probability to Size (PPS) of $3.0 \%$ of household heads/ water vendor (Table 1).

\begin{tabular}{|c|c|c|c|c|}
\hline S/N & Ward & $\begin{array}{c}\text { Estimated Population of } \\
\text { Household }\end{array}$ & $\begin{array}{c}\text { Estimated Population of Water } \\
\text { Vendor }\end{array}$ & $\begin{array}{c}\text { Sample } \\
\text { Size/Questionnaire }\end{array}$ \\
\hline 1 & Quarters (Phase i, ii \& iii) & 400 & 10 & $* 11 /^{* * 1} 1=12$ \\
\hline & Zuba & 3,000 & 105 & $* 68 / * * 23=91$ \\
\hline 3 & Central & 3,100 & 120 & $* 70 / /^{* *} 29=99$ \\
\hline 4 & Kuntunku & 3,700 & 80 & $* 89 / /^{* *} 21=111$ \\
\hline 5 & Gwako & 2,600 & 60 & $* 66 /{ }^{* *} 12=78$ \\
\hline 6 & Tunga- Maje & 350 & 25 & $* 9 /{ }^{* *} 1=10$ \\
\hline Total & 6 & 13,150 & 400 & 400 \\
\hline
\end{tabular}

Table 2: Estimated Population of Water Vendor and Sample Size Per Ward

Note: Column $5=$ * Sample Size for Household; ${ }^{* *}$ Sample Size for Water Vendor.

Source: Field Survey, 2017.

Table 2 shows that, there is variation in the number of household and water vendor in the selected wards; while the Quarters ward had the lowest number of household and water vendors, Kuntunku ward recorded the highest number of both the household and water vendors. This variation may be attributed to the fact that, Quarter ward was planned ward of the study area with water services and manageable population, whose carrying capacity had not been exceeded, though it is inadequate. On the other hand, the other wards were traditional in their structure, with high population density and visible absence of potable water.

\section{Sources of Water in the Study Area}

Water is vital in socio-economic development of human society. The source of water available to a people can determine the quality of their lives. Water is required for many purposes; thus, its availability in quantity and quality is of importance to geographers. For one, quality water, to a large extent, determines the productivity of a people. A healthy people are likely to be productive more than a sick society [22]. 


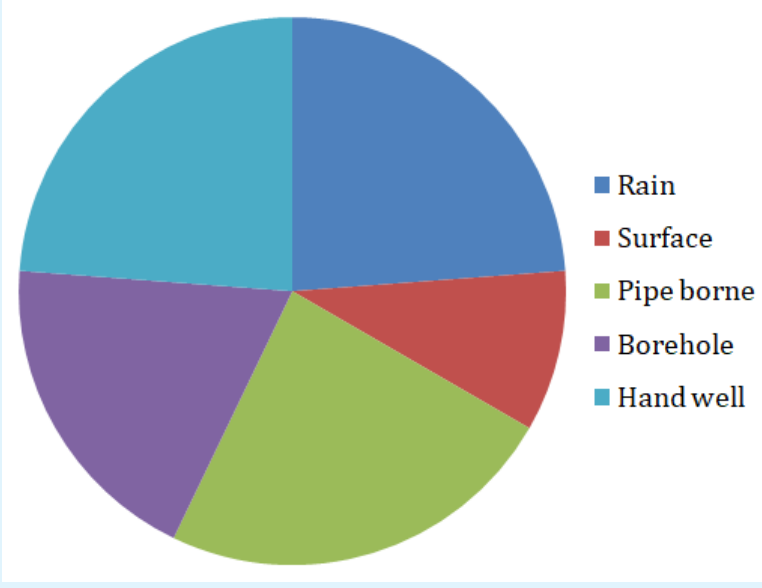

Figure 2: Sources of Water in the Study Area.

Source: Field Survey, 2017.

Figure 2, shows a vivid picture of the sources of water in the study area; $25.0 \%$ of the respondents in the study area rely on rain water (which is seasonal), while $5.0 \%$ of the respondents also rely on surface water. Furthermore, $25 \%$ of the respondents in the area take their water from public pipe borne water and $20 \%$ source their water from bore-holes. In the same vein, $25 \%$ of the respondents also sourced their water from hand wells, most of them were confined in compound. Of all the identified sources of water in the study area, the UNICEF ( ) submitted that, water from pipe borne and borehole sources were most safe sources of water.

The implication of this that, $55 \%$ of the people of the study area source their water from unsafe sources. In an in-depth interview (IDI), an opinion leader in the study area, it was submitted that most people source their water needs from wells, rivers/streams and lately from boreholes.

"Water situation here is pathetic, as we source water from unprotected sources.

In most cases, water from wells (a major source of water) is hard. Most

Rivers/streams recede with season, thus we are forced to live with unprotected

water" ((IDI, Central Ward, 2017).

The implication of these may be bad not only for the study area, but for the development of Nigeria. Rivers and streams are open to pollution because they are not protected, and as result of variation in season, rain water may not be available the year round. It follows therefore that people were forced to source their water from questionable sources.

In aligning with the above submissions, another opinion leader submitted that agreed that:

"We started getting relieved as a result of innovation of borehole technology and

supply from water vendors. Prior to that period, we sourced our water from open surface water" (IDI, Quarters Ward,2017 ).

Generally, the above scenario shows a poor state of water supply in the study area, as a larger percentage of people in the study area relied on rivers and streams for their water. This may be as result of general absence of pipe borne water in the area, high level of poverty among people in the area, and the level of ignorance among others. Accessibility to water in the study area varies from one area to another.

\section{Methods of Water Collection in Study Area}

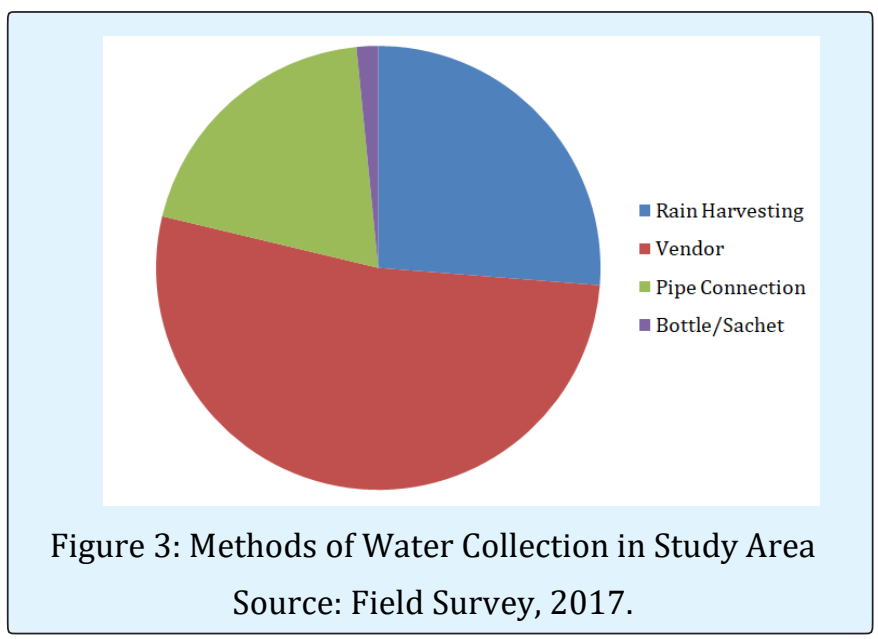

Figure 3 shows that $20.0 \%$ of the respondents obtained their water by harvesting rain water, while $40.0 \%$ get their water from water vendors. Similarly, $15.0 \%$ also connect their water from public water supply, while $25.0 \%$ collect their water through purchase of bottled/sachet water. This infers that, $15.0 \%$ of the respondents had access acceptable safe water delivery. This similar to the submission of a respondent in an interview with an opinion leader, who opined that:

"Water vendor has remained a major source of water for satellite residents of 
FCT. In my many years as a civil servant in the state, water vendor has assisted

many that I know of "(IDI, Angwa-Shanu, Gwagwalada Central Ward, 2017).

In the same vein, other discussants opined that, some of their household members had experienced waterborne disease at one time or the other. In another interview with a key government official of Water department, the population has outweighed the available water.

According to this source:

"The Gwagwalada Area Council receives part of its drinking water from the lower

Usuma dam. It is able to treat about 8,018,702 cubic of water monthly" (IDI,

Abuja Water Works, 2017).

Even though human water requirements were subject of debate as result of climatic variation, physical exercise and humidity, the fact remains that safe water is not adequate for human uses, not only in Nigeria, but in many developing countries of the World [23].

\section{Method of Analysis}

The Simple Chi-Square analysis was employed in this study and is of the form:

Where $0=$ Observed frequency distribution

$\mathrm{E}=$ Expected frequency distribution.

The choice of Simple Chi-Square analysis is informed by its power determines the level of differences between the observed and expected variables

\begin{tabular}{|c|c|c|c|c|c|}
\hline $\mathbf{S} / \mathbf{N}$ & Ward & $\mathbf{0}$ & $\mathbf{E}$ & \multicolumn{2}{|c|}{$(0-E)(0-E)^{2}$} \\
\hline 1 & Quarters(Phase i, ii and iii) & 16 & 15.3 & -0.3 & 0.09 \\
\hline 2 & Central & 16 & 15.3 & 0.7 & 0.49 \\
\hline 3 & Tung-Maje & 15 & 15.3 & -0.3 & 0.09 \\
\hline 4 & Zuba & 16 & 15.3 & 0.7 & 0.49 \\
\hline 5 & Kuntunku & 15 & 15.3 & -0.3 & 0.09 \\
\hline 6 & Gwako & 15 & 15.3 & -0.3 & 0.09 \\
\hline & $\sum=$ & & & & 1.34 \\
\hline & Cal. Value $=0.25$ & & & & \\
\hline
\end{tabular}

Table 2: Result of Simple Chi-Square Analysis on Perception of Respondents across the Study Area.

From the result of this study, $90.0 \%$ of the respondents were of the view that water vendor is an essential means of sourcing for domestic water. In the same vein, the result of simple Chi-square analysis shows that the table value is $\mathrm{X}^{2} 0.05,9=16.9$, while the calculated value is 0.25 as shown in table above.This infers that, there is significant relationship between water vendor and water needs of people of Gwagwalada Area Council, FCT-Nigeria [24-26].

These results may be attributed to a number of factors which include inadequacy in the supply of potable water, apathy of government toward the provision of potable water and poor education on the importance of safe water delivery among others [27-29].

\section{Conclusion and Recommendations}

The need for safe water is a rising trend in many parts of the world, because of its role in stabilizing the social system. Water is life as the continuous existence of man revolves around it. However, its availability in quantity and quality worries minds. There is variation in its availability and method of collection, as advanced countries have access to it than less developed countries and by extension method of collection. As result of this people are forced to source their water needs through various means including water vendor.

In Nigeria, the above scenario holds and this is manifested in Gwagwalada Area Council and by extension FCT where as result of influx of people, safe water has remained a mirage. This trend has made the FCT residents to source their through water vendor, with its attendant problems.

In the light of this, this paper recommends that, water vendor be formalized, in other to have legal backing. As it is currently, water vending system is considered to be business of every jack and harry. This can be achieved various agencies of the government. The business of water vendor should be regulated to make it a source of healthy and safe water to drink. Most water vendor operators in an appalling environment, using dirty equipment, and in most cases, vendor water are supplied in opened cans and cases and are not safe. Government (at all levels) should priorities provision of potable water. This will go a long way to stem the attitude of getting water from questionable sources with its attendant problems.

\section{References}

1. Jabeen $\mathrm{M}$, Mahmood Q, Tariq S, Nawad B, Elabi N (2011) Health Impact Caused By Poor Water and 


\section{Journal of Ecology \& Natural Resources}

Sanitation in District Abbottabad. In J Ayub Med Coll 23(1): 47-50.

2. World Vision Australia (2015) The Dangers of Dirty Water, The Power of a Safe, Clean Well.

3. Ayoade JO (1988) Tropical Hydrology and Water Resources. Lodon: Macmillan.

4. Tapio SK, Jarmo JH (2015) Social and Economic Importance of Water Services in the Built Environment: Need for More Structured Thinking. Procedia Economics and Finance 21: 217-223.

5. UNESCO (1987) The Role Of Water In Socio Economic Development. Report 1 of I HP- Project (On Heightening Awareness of The Socio-Economic Role Of Water) Prepared for the International Hydrological Programme by the Working Group of Project CI (IHPII).

6. UNDESA (2015) International Decade for Action Water for Life 2005-2015.

7. World Health Organization (2017) Diarrhea disease.

8. WHO/UNICEF (2015): Progress On Sanitation and Drinking Water-2015.

9. UNICEF (n.d.) Terms of Reference: Study on Wash Challenges in Peri-Urban Areas of Nigeria.

10. United Nations (2013) UN Water World Water Day; Facts and Figures.

11. UNICEF (2017) Over 57 million Nigerians Lack Access to Potable Water.

12. Bello MM (2017) FCTA Keen to Implement Water Supply Master Plan.

13. NPCN (2017) National Population Commission of Nigeria.

14. UNDP (2004) Water as a Human Right?

15. Ki MB (2011) Cited in UNDESA 2011: International Decade for Action Water for Life 2005-2015.

16. World Bank (2017) Access to potable water in Nigeria.
17. World Bank/ Federal Republic of Nigeria (2012) Water Supply and Sanitation Interim Strategy Note.

18. National Rural Water Supply and Sanitation Strategic Framework (2004) Prepared by the Department of Water Supply and Quality Control , Federal Ministry of Water Resources.

19. Omotoso O (2009) Water Pollution, Prevention, Control and Management: Int J Environ Issues 6(1-2): 204-215.

20. United Nations Centre for Habitat Studies Settlement, Environment (UNCHS 1994): A Journal on People and Development.

21. Centers for Disease Control (2012) Assessing Access to Water and Sanitation.

22. Moe CL, Rheingans RD (2006) Global Challenges in Water, Sanitation and Health. J Water Health 4: 14155.

23. Maton A, Hopkins J, Mc Laughlin CW, Johnson S, Warner MQ, et al. (1993) Human Biology and Health. Englewood Cliffs, New Jerssey, USA.

24. Akinsuyi Y (2015) 63Million Nigerians Lack Access to Potable Water.

25. Balogun $O$ (2001) The Federal Capital Territory of Nigeria: Geography of its development, Ibadan University Press, University of Ibadan.

26. Muta'a Hellandendu J (date not stated) Health Implications of Water Scarcity in Nigeria. European Sci J 8(18): 111-117.

27. Ochekpe S (2015) 70 Million Nigerians Lack Access to Potable Water. The Punch News Paper.

28. UNESCO (n.d) Water Drives Job Creation and Economic Growth.

29. World Health Organization/UNICEF (2012) Progress on Drinking Water and Sanitation: WHO/UNICEF Joint Monitoring Programme for Water and Sanitation.

Urban: A Case of Gwagwalada Town, Gwagwalada Area Council Federal Capital Copyright $(\subset)$ Omotoso 0 and Akanbi OA. Territory (Fct), Nigeria. J Ecol \& Nat Resour 2018, 2(6): 000149. 